\title{
A case of severe cutaneous Mycobacterium marinum infection in a patient with Crohn's disease on chronic high-dose prednisone
}

\author{
Takaaki Kobayashi, ${ }^{1}$ Bradley Ford, ${ }^{2}$ Poorani Sekar ${ }^{1}$
}

${ }^{1}$ Department of Internal Medicine, Infectious Diseases, University of lowa Hospitals and Clinics, lowa City, lowa, USA ${ }^{2}$ Department of Pathology, University of lowa Hospitals and Clinics, lowa City, lowa, USA

\section{Correspondence to}

Dr Takaaki Kobayashi, taka.kobayashi1126@gmail.com

Accepted 12 December 2018

\section{DESCRIPTION}

A 73 year-old man with a history of Crohn's disease was referred to the infectious diseases service for rash. Three months ago, he developed a diffuse rash that was neither itchy nor painful. He had been taking prednisone $40 \mathrm{mg}$ daily for Crohn's disease for 40 years. He had both a salt and fresh water fish tank that he routinely cleaned and maintained. He denied fever, cough, recent travel or sick contacts. Skin examination revealed several erythematous nodular lesions on bilateral hands and erythematous papules on his chest, abdomen, face and extremities (figure 1A,B). Biopsy of the rash was performed, and Tissue Gram stain showed long, beaded Gram-positive rods that were also acid-fast by Ziehl-Neelsen stain (figure 2A). Given the appearance on histopathology, Nocardia was suspected and trimethoprim-sulfamethoxazole was started empirically. The patient's lesions improved. Culture eventually grew Mycobacterium marinum. Since his rash improved with trimethoprim-sulfamethoxazole, it was continued and rifabutin was added given the severity of his rash. At 1-month follow-up, his rash improved with plans made for continued treatment for a few months after the resolution of all skin lesions.

M. marinum is a photochromogen that produces a yellow pigment when exposed to light (figure 2B). It grows slowly (usually between 2 and 3 weeks, but up to 8 weeks) at lower temperatures (ranging from $25^{\circ} \mathrm{C}$ to $32^{\circ} \mathrm{C}$ ). M. marinum lives in fresh and saltwater and is carried by many fish species. Human infection ('fish tank granuloma') occurs via

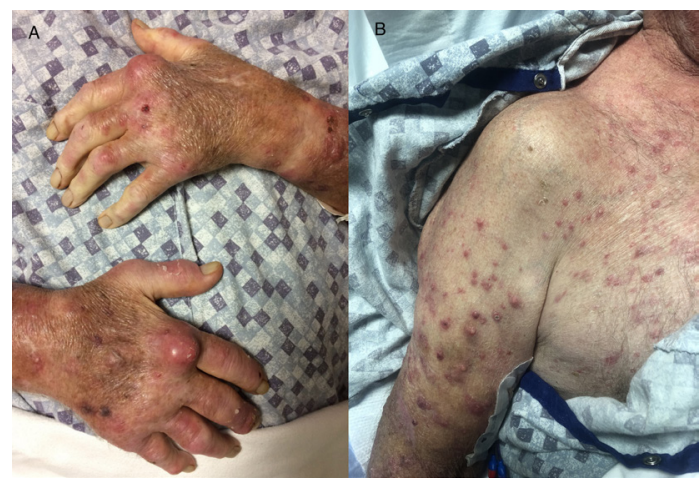

Figure 1 (A) Erythematous and fluctuant soft papulonodular lesions on bilateral hands overlying the second metacarpophalangeal joint. (B) Erythematous papules/pustules on chest, abdomen, back, face and extremities.

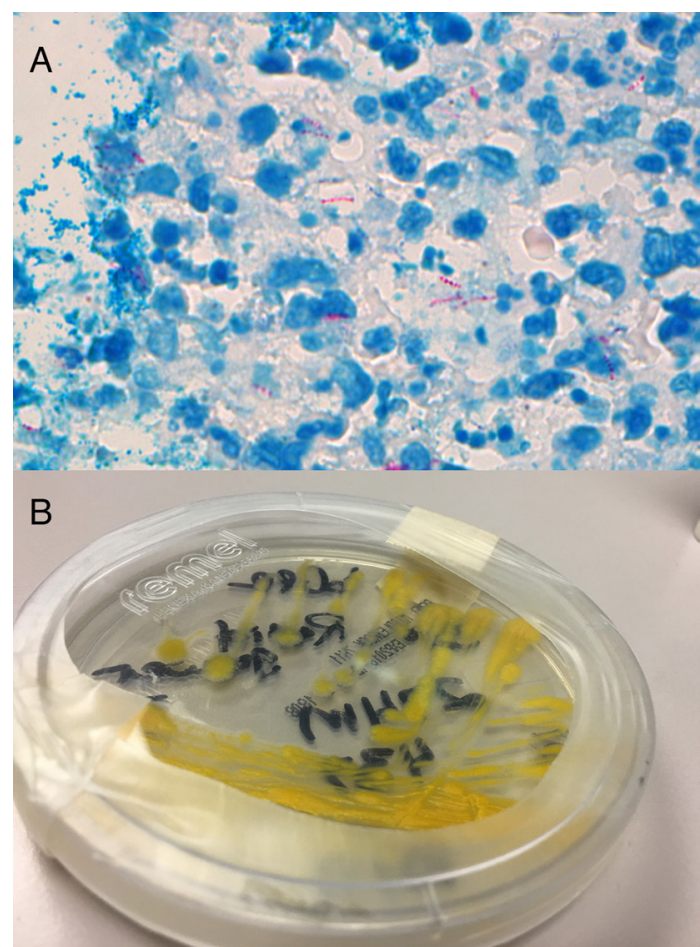

Figure 2 (A) Ziehl-Neelsen stain of tissue biopsy, $\times 100$ objective. (B) Mycobacterium marinum culture on $7 \mathrm{H} 11$ media, after approximately 14 days of incubation at $30^{\circ} \mathrm{C}$.

inoculation of the skin through fish bite or exposure of open wounds to contaminated water or an aquarium. In a recent report, 53 out of 63 (84\%) patients with $M$. marinum infections had inoculation related to fish-tank exposure. ${ }^{2}$ Cutaneous lesions usually occur in the cooler upper extremities 2-3 weeks after initial injury. Lesions are often solitary, sometimes multiple and in $25 \%-50 \%$ of patients lesions may spread along lymphatic channels called 'sporotrichoid spread'. Differential diagnoses include nocardiosis, histoplasmosis, blastomycosis, syphilis, sporotrichosis, Mycobacterium tuberculosis or tularaemia. Definitive diagnosis is made from the acid-fast bacillus culture of specimens and potentially from PCR of tissue. It is important to have a high degree of suspicion, ask questions about environmental exposure and to alert the laboratory when M. marinum is on the differential so that the specimen can be cultured optimally.

While surgical intervention may be needed for treatment of infections involving deep tissue structures, cutaneous lesions caused by M. marinum are managed with antimicrobials. In contrast to the 
standardised treatment for M. tuberculosis, there is no standard treatment for M. marinum, nor is there standardised susceptibility testing. Research susceptibility testing and clinical outcomes suggest combination therapy with two active agents ${ }^{2}$ for moderate to severe infections. Antimicrobials include clarithromycin, ethambutol, rifampin, minocycline, doxycycline and trimethoprim-sulfamethoxazole. Some recommend antimicrobial monotherapy for

\section{Learning points}

- For patients with painless nodular lesions, especially on the hands or upper limbs, it is important to ask about history of water and fish-tank exposure. If concerned about Mycobacterium marinum, the microbiology laboratory should be alerted to set up cultures at a lower temperature.

- Combination therapy of two active agents is recommended for moderate to severe cutaneous $M$. marinum infection.

- There is no definite guideline on treatment duration, however antibiotics are generally continued until a few months after resolution of skin lesions. mild disease. Susceptibility testing is not routinely recommended and should be reserved for cases of treatment failure. Optimal duration of therapy has been evaluated in case series. Treatment is continued until 1-2 months after the resolution of skin lesions, typically $3-4$ months in total. ${ }^{3}$

Contributors TK wrote the first draft of the manuscript. PS and BF critically reviewed and revised the manuscript. All authors read and approved the final paper.

Funding The authors have not declared a specific grant for this research from any funding agency in the public, commercial or not-for-profit sectors.

Competing interests None declared.

Patient consent Obtained.

Provenance and peer review Not commissioned; externally peer reviewed.

\section{REFERENCES}

1 Aubry A, Mougari F, Reibel F, et al. Mycobacterium marinum. Microbio/ Spectr 2017;5.

2 Griffith DE, Aksamit T, Brown-Elliott BA, et al. An official ATS/IDSA statement: diagnosis, treatment, and prevention of nontuberculous mycobacterial diseases. Am J Respir Crit Care Med 2007;175:367-416.

3 Lewis FM, Marsh BJ, von Reyn CF. Fish tank exposure and cutaneous infections due to Mycobacterium marinum: tuberculin skin testing, treatment, and prevention. Clin Infect Dis 2003;37:390-7.

Copyright 2018 BMJ Publishing Group. All rights reserved. For permission to reuse any of this content visit https://www.bmj.com/company/products-services/rights-and-licensing/permissions/

BMJ Case Report Fellows may re-use this article for personal use and teaching without any further permission.

Become a Fellow of BMJ Case Reports today and you can:

- Submit as many cases as you like

- Enjoy fast sympathetic peer review and rapid publication of accepted articles

- Access all the published articles

- Re-use any of the published material for personal use and teaching without further permission

For information on Institutional Fellowships contact consortiasales@bmjgroup.com

Visit casereports.bmj.com for more articles like this and to become a Fellow 